\title{
A TÚLÉLŐ SZERVEZET
}

\author{
KOZMA TAMÁS \\ Debreceni Egyetem
}

Beérkezett: 2021. május 4., elfogadva: 2021. október 21.

A szervezetkutatások egyik régóta ismert megállapítása a „szervezeti túlélés”. Ez annyit jelent, hogy a szervezet képes fönnmaradni akkor is, ha a szükséglet, amelynek betöltésére létrejött, többé már nem létezik. Az OECD története jól illusztrálja a szervezeti túlélést. Elődszervezetének keletkezése (1947), eredeti funkciója, majd szervezeti válsága (1961) és új szükségletek felfedezése, illetve kialakítása modell értékű. Arra példa, hogy egy nemzetközi szervezet hogyan alakult át, hogyan tudott beilleszkedni a 20. század második felének rohamosan globalizálódó világába, és hogyan tette magát nélkülözhetetlenné. Kialakított egy narratívumot, amely az OECD énképén és filozófiáján alapszik, és amelyet sajátos nyelvezet hordoz. Mindenekelőtt pedig olyan új szükségleteket termelt ki, amelyeket saját maga képes kielégíteni. Mindez jól tanulmányozható abban, ahogyan az OECD a rendszerváltozás után Kelet-Közép-Európában megjelent.

Kulcsszavakः szervezetkutatás, globalizáció, OECD, Kelet-Közép-Európa

The phenomenon 'organisational survival' is known in organisational research. It means that an organisation remains still active even if the need for it does not exist any more. The history of the OECD is an illustration of organisational survival. The emergence of its predecessor (OEEC, 1947), the original function of the 1947-organisation, its crisis (1961), and the hunt for new needs have model values. It is an example of how an international organisation has evolved, integrated into the rapidly globalising world of the end of the twentieth century and how it made itself indispensable. The OECD has developed a narrative based on its self-image and philosophy and carried by a specific 'OECD-language'. Above all, OECD has produced new needs that only it could meet. The process can be studied in the appearance of the OECD as it moved to Central and Eastern Europe after the political turn of 1989/90.

Keywords: organisational survival, globalisation, OECD, Central and Eastern Europe

Levelező szerző: Kozma Tamás, Debreceni Egyetem, 4032 Debrecen, Egyetem tér 1.

E-mail: kozmat@iif.hu, ORCID: 000-0002-6971-8104 


\section{Bevezetés}

A rendszerváltozás hajnalán az akkori oktatásügyi miniszter nem tudta, mi az az 1 OECD; keresnie kellett egy olyan beosztottját, aki tudta. Nem volt könnyű ráta$\triangle$ lálni. Az 1990-es évek elején az OECD jórészt ismeretlen volt Magyarországon (az UNESCO-t ismerték a legtöbben). Az MTA Pedagógiai Bizottságának egyik tagja egy ülés után lehalkított hangon, hogy mások ne hallják, azt kérdezte: tulajdonképpen mi is az az OECD? Sokak nevében beszélt.

Azóta harminc év telt el. Az OECD (Organisation for Economic Co-operation and Development) Gazdasági és Fejlesztési Együttmüködési Szervezet fontos lett az ország számára - Magyarország 1996 óta a szervezet tagja -, és fontos nekünk, oktatáskutatóknak is. Nem annyira fontos persze, hogy fönntartás nélkül dicsérjük; inkább távolságtartással. $\mathrm{A} z$ alábbi írás egy ilyen távolságtartó vélemény. $\mathrm{Az}$ OECD-t a túlélő szervezet példájaként láttatja. Előbb értelmezzük, hogy mit értünk „túlélő szervezeten", majd az OECD történetén illusztráljuk a szervezeti túlélést; rámutatva a túlélés okaira és eszközeire. Végül visszapillantunk azokra az évekre, amelyekben az OECD itthon és Kelet-Közép-Európában megjelent.

\section{Szervezeti túlélés}

Szervezeti túlélésről akkor beszélünk, ha egy szervezet elveszti az eredeti funkcióját a társadalomban, mégis megmarad, új szükségleteket és funkciókat keresve magának (Szczepański 1969; Haas 2008 - további irodalommal). A jelenség közismert. Nagy társadalmi szervezeteink alakváltozásaira gondolhatunk; például a gazdasági szervezetek termékváltásaira. Hasonlóképp élnek túl a társadalom szervezeti tartóoszlopai, például az egyházak, a politikai és szakszervezetek vagy a közigazgatás (a bürokratikus szervezetekről 1. Morawski 1979; Szentpéteri 1985).

Bár a jelenségek szerteágazók, a szervezetkutatás mégis talál bennük hasonlóságokat. Már a „szervezet” definíciója is a tartósságra utal. Ha az emberi tevékenységek összehangolásának fogjuk föl a szervezést - terméke a szervezet -, akkor éppen a koordináció biztosítja a tevékenységek (a munka) állandóságát, ismételhetőségét és fönntarthatóságát. (Az itt következők részletesebben is olvashatók a Bevezetés a nevelésszociológiába megfelelő lapjain, vö. Kozma 1999, 2001: 85-103).

Éppen ez a szervezés jelentősége az innovációval szemben. Az innováció a változást, megújulást, átalakulást - hosszú távon a fejlődést - hordozza; a szervezés pedig az innováció elterjesztését és fönntarthatóságát. A kettő - innováció és szervezés - összetartozik, az érem két oldala. Az innováció mozgalom: kezdete, fölívelése, hanyatlása, elmúlása van, mint minden társadalmi mozgalomnak, amely spontán módon, egy adott közösségben megindul és terjedni kezd. A szervezet állandóság: arra szolgál, hogy a mozgalmat tartósítsa, biztosítva a múlt sikeres tapasztalatainak továbbadását és tartóssá tételét.

Tér és torony címü monumentális írásában Niall Ferguson a kettőt frappánsan szembeállítja (Ferguson 2019). Azt mondja, hogy a közösségek mozgalmai hordozzák az innovációt - ezt jelképezi a tér, még inkább a piac -, a társadalmi szervezetei pedig 
lassítják, akadályozzák, végső soron elfojtják az innovációkat. Ez persze nem igaz. Tér és torony - vagyis szervezetek és mozgalmak, innovációk és a fönntarthatóság csak a vita kedvéért van szembeállítva. A megőrzés, a továbbadás és az újítás minden átalakulás kulcsfontosságú lépései, amelyeket a közösségi tanulás köt össze egymással (Márkus-Kozma 2019).

A szervezetek stabilitásának titka - a spontán közösségekkel és mozgalmakkal szemben - a hierarchikus felépítés. A hierarchikus fölépítés alá-fölérendeltséget jelent, és centralizált formában müködik. A hierarchia lépcsőin fölfelé haladva a szervezet tagjainak mind több a hatalmuk és egyre több a felelősségük is (az eredeti papi szervezetek csúcsán a transzcendens hatalom állt). A centralizált müködésen pedig azt kell érteni, hogy a döntések (felelőssége) a hatalmasok kezében van; a végrehajtás pedig az alsó fokokon lévőkre marad.

Minél hagyományosabb egy szervezet és minél hosszabb ideje működik, annál erősebb benne a hierarchia és a centralizáció. Némi túlzással azt is mondhatnánk, hogy nem emberek, hanem szerepek struktúrája, amelyben a szervezeti szerepek a fontosak, nem pedig azok, akik betöltik ezeket a szerepeket. Ha a szervezet egy tagja kilép, helyére nem hozzá hasonlót keresnek, hanem olyan valakit, aki az adott szerepet be fogja tölteni. Ehhez is tanulás kell; de a szervezeti betanítás nem tévesztendő össze a közösségi tanulással, amely javarészt spontán.

Bár a szervezet is „él” - azaz születik, fejlődik és elmúlik -, mégis az állandóság jellemző rá.

A szervezet „életciklusai” az egyik kedvenc témája a különböző szervezetkutatásnak, amilyen például a családkutatás. A szervezeti változások egyik magyarázata a szervezeteken belül rejlö közösségek folyamatos átalakulása. (Lásd: Mayntz 1969.)

A z állandóságot látható jelek szimbolizálják - pl. zászlók, címerek, formaruhák -, hangsúlyozva, hogy minél régebbi a szervezet, annál megbízhatóbb. A szervezeti szerepek állandósága miatt jellegzetes szervezeti kultúra alakul ki (intézmények, magatartásminták, értékek, szankciók). Mindez azt sugallja, hogy válságok, váratlan kihívások és rögtönzött döntések idején a szervezethez érdemes fordulni, amely hitelesen megörzi az egyszer már bevált tapasztalatokat.

Ez éppen fordítottja annak, ami egy társadalmi innováció alkalmával történik. Társadalmi innováció ugyanabból a válságból születik meg, amelyre a szervezet a maga állandóságával válaszol. A szervezet adja a hagyományos választ a kihívásra, az innováció pedig olyan választ, amellyel még nem kísérleteztek. Ha beválik, ez volna a jó válasz, amelyet terjeszteni kellene. Csakhogy a szervezet - értelemszerűen - ellenáll (Moulaert et al. 2013).

Ez az ellenállás a túlélés magyarázata. A szervezetben együttműködők abban érdekeltek, hogy a szervezet biztonságot és tartósságot nyújtson nekik. Ezért érdekük a szervezet sikere. Ha a szervezet válaszai a nagy sikerekre már nem érvényesek, keresnek más kihívást, ahol megint sikeresek lehetnek. Vagyis a szervezet túléli a saját kudarcait és 
fölöslegessé válását azzal, hogy új problémákat keres, amelyeket meg tud oldani. S ha nem talál ilyen problémákat, akár ki is alakítja, meg is teremti őket.

A szervezeti túlélés, úgy véljük, alkalmas arra, hogy az OECD esetét értelmezni tudjuk. Alább az OECD történetét mint a túlélő szervezetek egy példáját fogjuk bemutatni.

\section{Narratívum és valóság}

Az OECD 1961-ben alakult, létezését azonban elődintézményére, az 1947-1948-ban szerveződött OEEC-re (Organisation for European Economic Cooperation, 1948) vezeti vissza. Az OEEC-t azért alapították, hogy az európai Marshall-segélyt levezényelje. A $z$ ún. Marshall-segély az európai országok újjáépítését volt hivatott támogatni a világháború után.

A Marshall-segély igazi amerikai vállalkozás volt. Arra hivatkozva, hogy a szövetségesek lebombázták Európa jó részét, újjáépítési segélyt ajánlottak Európának, beleértve a veszteseket csakúgy, mint a nyerteseket. Erről sokáig a közvélemény csak az amerikai pénzt és gesztust tudta (a KGST-országok szovjet kezdeményezésre elutasították). A rendszerváltozás óta azt is tudjuk, hogyan szerveződik az ilyen segély. Nemcsak a pénzek érkeznek, hanem a kikötések is, hogyan kell elkölteni őket. Így a segély beruházás és piacépítés is egyben. (Mezei 2001.)

$\mathrm{Az}$ OECD-narrativumok szerint mintha ez a segély csupán melléktevékenység lett volna egy fontosabb és erőteljesebb kezdeményezéshez: a kiterjedtebb és egységesebb európai piac kialakításához, amely természetesen politikai egyeztetéssel jár (lásd pl. OECD 2021g; OECD 2021b; OECD 2021j). S a Marshall-segély megszervezése és elosztása mintha ennek az egységesítő piacépítésnek az eszköze lett volna. Még inkább annak a szándéknak a kifejezése, hogy a pusztító európai háború után az amerikaiak is hozzájárulnak az egységesedő Európához - egy képzeletbeli „Európai Egyesült Államokhoz". (A francia kezdeményezésű egyesült Európa projekt keresztezte ezt az elgondolást a maga montánuniójával, 1951).

$\mathrm{A} z$ OECD-narratívumok úgy folytatódnak, hogy amikor a piacépítésnek ez a szakasza véget ért, a szervezet megváltoztatta a nevét, és OECD lett belőle (1961). A valóság ennél bonyolultabb. A Marshall-projekt lezárulásával kihátrált az amerikai kormányzati pénz a szervezet mögül, amellyel az egységes piacépítést folytathatta volna, és a szervezet növekvő válságba került. Az 1950-es évek második felében már eljutott odáig, hogy a megszünés fenyegette (az európaiak, részben az amerikai kezdeményezések hatására is, megkezdték a saját piacépítésüket, egy jövőbeni európai közös piac alapjainak lerakását). A szervezet új támogatókat kellett keressen, mert az európaiak mind kevesebb tanácsot kértek és mind kevesebb pénzt adtak egy amerikai piacépítéshez Európában. Az egyszerű névváltoztatás mögött szervezeti átalakulás állott: az Egyesült Âllamok és Kanada megnyerése egy új, gazdaságfejlesztő szervezet megalakítására, amelynek már nem Európa volt a célpontja, hanem az egész világ.

Ezzel a sikeres válságkezeléssel zárul az OECD első szakasza - az előtörténet -, és indul a szervezet történetének második fejezete. Ezt a fejezetet az OECDnarratívumok a kiteljesedés történeteként szokták elmondani. Ekkor alakult át - máig tartó érvénnyel - az OECD mint a "fejlett" (gazdag) országok tanácsadó irodája. Gaz- 
dasági (és oktatási) indikátorokat munkál ki az egyes fejlesztési területek összehasonlíthatósága végett, hogy aztán tagjai (az egyes kormányok) közremüködésével föltöltse őket adatokkal, és elemzéseket készítsen belőle. Részben a tagok igényei szerint, részben a tagok fejlesztési eredményeinek egybevetésére (benchmarking). Ennek a tevékenységnek néhány eredménye szakmai körökben, sőt a tágabb közvéleményben is ismertté vált. Az Education at a Glance az oktatás és oktatáspolitika általánosan használt referenciakiadványává alakult (OECD 2020). A PISA vizsgálatok eredményeit pedig hol az adott kormányzat sikereként könyvelik el, hol pedig nemzethalálként interpretálják (lásd: PISA 2015).

George Papadopoulos (1926-2013) - ennek a második állomásnak a leghitelesebb krónikása -, ezt a szakaszt nem egyszerüen kiteljesedésnek írja le, hanem a szervezet belső konfliktusainak történeteként (Papadopoulos 1994). Az „aranykor” után ahogy Papadopoulos az újjászerveződés első évtizedét nevezi -, az 1970-es évek első felében az OECD ismét hullámvölgybe került. Ebből előbb belső reformokkal igyekezett kilábalni, majd „új kiegyezésre” törekedett „a társadalommal”. Az 1980-as évek első felében egy recessziós hullámot vészelt át, amelyből az évtized végére szervezeti átalakulással próbált szabadulni. Annál is inkább, mert az 1980-90-es évtizedek fordulóján új kilátások nyíltak előtte: A szovjet birodalomból kilábalt közép- és kelet-európai országok egymással versengve jelentkeztek az OECD tagságába, és igényelték gazdaság- és oktatásfejlesztési tanácsait. (Az OECD-tagdíj nem kevés, és hozzájárul a szervezet mint tanácsadó központ fennmaradásához.)

$\mathrm{A} z$ OECD-t magyarázó és népszerüsítő hosszabb-rövidebb előadások (lásd $O E C D$ 2021g; OECD 2021h) mit sem tudnak erröl. Persze, nem is ez a dolguk. Inkább olyan narratívumokat adnak elö, amelyek nagyon hasonlítanak egy modern „üdvtörténetre”. Eszerint az OECD a szociálisan megszólított szövetséges hadviselők kezdeményezésére jött létre, és amikor küldetését betöltötte, megváltoztatta a nevét, hogy tapasztalatait és jótéteményeit az egész világgal megoszthassa. Ez az „üdvtörténet” - a kezdetektől máig - egyenesen halad elöre, hogy elérje a végkifejletet, amely most van (a világkereskedelem fejlesztésével [sic!] a koronavírus-járvány ellen, vö OECD 2021c). S amelyet a szervezet egyik jelszava fejez ki: Tudás és méltányosság (OECD 2021b). Tudás arról, hogyan kell a gazdaságot fejleszteni - és méltányosság azok iránt, akik a fejlesztést megszenvedik.

\section{A túlélés záloga}

A túlélés záloga, hogy a szervezet kitalálja azt a szükségletet, amelyet ki tud elégíteni, a környezet pedig felismerje, hogy az valóban az ő szükséglete. Nem véletlenül nevezi Papadopoulos az OECD újjáalakulásának első szakaszát „aranykornak”. Az 1960-as évek első szakasza a háború utáni újjáépítés lezárulása, a volt gyarmati országok felszabadulása, a „világ háborújának” (Ferguson 2020) új szakasza volt. Kiderült: az OECD közremüködésére - különösen új támogatói bevonásával - még nagyobb szükség van, mint korábban.

Kiszabadulva egyrészt a Marshall-segély adminisztrációs béklyóiból, másrészt a piacépítés konfliktusaiból - amelyeket többek között az önállósodó európai „közös piac” jelentett - a szervezet előtt új távlatok nyíltak. A szűkre szabott és konfliktusossá vált 
Európa helyett a legfejlettebb országok tanácsadója lenni olyan új funkció volt, amelyre az OECD több mint tíz év tapasztalatai és kapcsolatrendszere révén fölkészült lehetett és sikeressé vált. Ez okozhatta az „aranykor” érzetét. Egyben természetesen a szervezeti változások sorozatát, ahogy 1960-1970 fordulójának belső történései mutatták.

Ekkor alapozódott meg az OECD új, szervezeti narratívuma. Ez a narratívum részben a környezet meggyőzésére szolgált, és a sikereket emelte ki. Részben azonban megrajzolta a szervezet önképét is. Ebben az önképben az új szükségletek kialakítása és elfogadtatása a tagállamokkal a szervezet „hivatásának” tünt, amellyel a kormányzatok segítségére siet; a szervezet saját maga által kialakított filozófiája pedig valamifajta tudományos fölismerésnek (pl. az oktatás szerepe a gazdaságfejlesztésben), amelyen a szervezet tevékenysége alapul. Az OECD mai narratívumai tudományosan megalapozottnak és történetileg szükségszerünek tekintik azt, amit maga a szervezet egykor önmeghatározásként fogalmazott meg.

A szervezet átalakulásához új nyelvhasználat kellett. Ebben az új fogalomhasználatban pl. az „emberi jogok” nem valamennyiünk joga, hanem a szervezet tagjaié (részvényeseié, shareholders) arra, hogy részesüljenek a profitból, és szabadon gazdálkodhassanak a részvényeikkel. A tájékozódás szabadsága jelenti a részvényesek jogát a vállalat müködésének megismerésére; a részvétel szabadsága pedig a jogot arra, hogy részt vehessenek a gazdasági döntésekben (OECD 2021b).

Oktatási vonatkozásban talán a legbeszédesebb a „kompetencia” fogalmának színeváltozása (OECD 2021i). A szó eredetileg „hozzáértést” jelentett, képességet és készséget valamilyen, rendszerint gyakorlati feladat elvégzésére. A nemzetközi tanulmányi teljesítményméréseket hosszabb ideig akadályozták a részt vevő kormányok azzal, hogy más és más tantereik vannak, amelyek más és más követelményeket fogalmaznak meg az iskolában, s ezért összehasonlíthatatlanok. Így tehát a szakértők tantervi követelmények helyett „kompetenciákat” fogalmaztak meg, amelyek adott életkorban mindenkitől elvárhatók, és így nemzetközileg egybevethetők. A kifejezés karrierje mutatja az átértelmezés kényszereit, amelyet a szervezeti túlélés kitermel.

A szervezeti túlélés egyfajta ostromállapot. A szervezet tagjai sajátos magatartásokat vesznek föl és alakítanak ki, másokkal és egymással szemben tipikus elvárásokat támasztanak. Ez minden szervezetben így van - a nemzetközi szervezetekben azonban különösképpen. A magatartások - amelyek egy idő után személyiségvonásainak tűnnek - részben abból származnak, hogy az OECD munkatársai jóval tájékozottabbak a világban, mint az egyes tagállamok kormányzati tisztviselői. Részben természetesen szakértői tudásukból, mivel az OECD munkatársai közé emelkedni minden nemzeti szakértő karrierjénak a csúcsa. Részben pedig a pozicióikból, mivel egy nemzetek fölötti szervezet képviselőinek tünnek.

$\mathrm{A} z$ OECD szakértőinek - mint minden szakértőnek - nincs kormányzati felelőssége; csupán tanácsot ad. A kormánytisztviselőnek viszont van felelőssége, a kormánynak pedig még inkább (hiszen választják). Így az OECD-szakértő olyan tanácsokat adhat, amely a szakértelmétől telik és szerinte szakmai-tudományos szempontból a legjobb. A tagországok kormányzata viszont udvariasan hallgatja és óvatosan alkalmazza. Ez 
mélyen rejlő, de nyilvánossá váló konfliktusokat okozhat szakértő és kormányzati tisztviselő között. Az eredmény az olyan szakértői magatartás, amely lenézi a kormányzati tisztviselőt (vagy a nemzeti szakértőt) - miközben elidegenedik egy-egy tagország kormányzati valóságától. A nemzetközi szakértő megy, a kormányzati tisztviselő marad. Az egyik felvilágosultnak látszik, a másik maradinak - holott csupán saját helyzetükhöz alkalmazkodnak.

A nemzetközi szakértő - különösen, ha már befutott - honi szempontból „gyökértelennek" látszik. Miközben beilleszkedik szervezetébe, fokozatosan kimarad az otthoni kapcsolatokból (még magánéletileg is). Ez különösen karrierjének végén veszélyes: nincs kihez fordulni, nehéz hová visszavonulni. Ez teszi a nemzetközi szakértöt különösen sérülékennyé. (A hidegháború idején különösen sebezhetők voltak azok a szakértők, akik a vasfüggöny mögül kerültek az OECD-hez; szerencsére a rendszerváltozás segített rajtuk.) A sérülékenység a magánéletben is megmutatkozhat (pl. a családban vagy a nyelvhasználatban, a közéletben vagy az akadémiai életben). (Lásd erről: Feitsma-Shillemans 2019.)

Mindennek eredménye egy sajátos szakértői magatartás, amely kívülről fölényesnek és zárkózottnak látszik - meglehetős ellenszenvet keltve -, míg a tárgyalások során törékeny és könnyen zavarba hozható, mivel nem ismeri kellően a környezetet, amelyben tanácsot kell adnia. Míg felkészültsége és áttekintő képessége megkönnyíti a tanácsadást, addig „felelőtlensége” és ismerethiánya kudarcossá teheti azt.

\section{Gazdaságfejlesztés és oktatás}

Az OECD már idézett jelmondata - Tudás és méltányosság - jól tükrözi a szervezet filozófiáját. Ez a filozófia a 20. század második felében alakult ki, és jellemzi a nemzetközi gazdasági szervezeteket. Úgy foglalhatnánk össze, hogy a kormányzati gazdaságfejlesztés - ebben érdekelt és jártas az OECD - az államirányítás csúcsairól előbbutóbb leszivárog, és eléri a társadalmat, amely végső soron profitál ebből. A kormányzati gazdaságfejlesztés is egyfajta "társadalmi szolgálat” - csakhogy nem a szociálpolitika, hanem a gazdaságpolitika oldaláról. A gazdasági fejlődés növeli az egyenlőtlenségeket. Hogy a gazdaságfejlesztés politikailag stabil környezetben történhessék, természetesen az OECD is érdekelt az együttmüködő kormányzatok stabilitásában - sőt, a gazdaságfejlesztés éppen ezt szolgálja (OECD 2021g).

Ebbe a filozófiába az oktatás fejlesztése - amely az OECD egyik prioritása - úgy illeszkedik be, mint a gazdaságfejlesztés egyik eleme (Rizvi-Lingard 2009). Az OECD oktatási szakértői visszanyúlnak a múlt század oktatásgazdászaihoz (Schumpeter, Douglas, Tinbergen), akik megalapozták az oktatásgazdaságtant, kialakítva azt a nézetet, hogy az oktatás a gazdaság fejlődésének egyik, ha nem a legfontosabb eleme. Ezt a nézetet azóta sokan bírálták (Polónyi 2002: 72-82) - mégis az OECD filozófiájának egyik alapját képezi. Innen nézve az oktatás és gazdaság ok-okozati összefüggése ideológiává vált: a szervezet filozófiájának része. Azaz nem tudományos probléma többé.

$\mathrm{A} z$ OECD CERI (Centre for Educational Research and Innovation, OECD 2021a) a szervezet oktatási szektorának igazgatóságához tartozik, tagjai pedig a tagországok képviselöi. Programjai e sorok írásakor (2021): nemzetközi oktatásstatisztika (Education at a Glance); az innováció mérése az oktatásban; az oktatást formáló trendek; 
a jövő oktatási kormányzása; tanárvizsgálat; az oktatás digitalizálása („smart data”); a 21. századi gyermek; a szociális és érzelmi készségek tanulmányozása.

A CERI jelentései, javaslatai és nyilvánosságra hozott dokumentumai sokszínű „pedagógiát” tükröznek. Egyrészt föltűnnek bennük a modern irányzatok (pl. az innováció fontossága vagy a közösségi tanulás elsődlegessége a formális tanítással szemben, vö. Kearns-Papadopoulos 2000). Másrészt azonban a tanár a kulcsember, az oktatás különböző helyszínei közül pedig az iskola (lásd pl. OECD 2021b). Ezek müködőképességét ugyanis kormányzatok biztosíthatják (míg például az egész életre szóló tanulást nyilvánvalóan nem). E pedagógiai keretben lehetséges az oktatás megújítása akár felülről - reformokkal -, akár alulról, innovációkkal. Az új és a hagyományos gondolati ötvözetét mutatja be Halász Gábor monumentális munkája, tükrözve, ahogy az OECD sokszínü „pedagógiája” formálja a CERI egyik vezetőjének gondolatvilágát (HalászFazekas 2021).

$\mathrm{Az}$ OECD oktatással kapcsolatos vállalkozásai közül napjainkra az ún. PISA vizsgálatok váltak a legismertebbekké (PISA: Programme for International Student Assessment, lásd erről: PISA ibid.). A PISA vizsgálatok a múlt század 60-as éveiig nyúlnak vissza, amikor a nemzetközi tanulói teljesítménymérések az UNESCO (International Institute of Educational Planning) védnöksége alatt elkezdődtek (Tudásszintmérés világszerte 1971; Kozma et al. 1979). Ezek a teljesítménymérések azonnal az oktatáspolitika viharába kerültek; részben mert rangsort mutattak ki a részt vevő országok között, részben mert egy-egy oktatási rendszerről bizalmas információk derültek ki (pl. óraszámok, tantervi adatok, tanítási föltételek és körülmények). Az 1990-es évek végén az OECD fölkarolta ezt a kezdeményezést, és kétévente elvégzi a maga vizsgálatát.

A PISA vizsgálatok (az első 2000-ben folyt le) több szempontból is beszédesek. Céljuk a kormányzati tájékoztatás. Adataikból nem lehet a résztvevőkre - sem intézményekre, sem tanulókra vagy pedagógusokra - visszakövetkeztetni, mert az OECD partnerei nem az intézmények, hanem a kormányok. Az egyes kormányzatokat igyekeznek meggyőzni az oktatásfejlesztésről azáltal, hogy a közvéleményt is bekapcsolják a média révén. A PISA-eredmények ismertetése kétévenként nagy médiakampánnyal indul. Ennek értelme a közvélemény nyomásán túl az összehasonlítás. Ha a szomszéd országok és/vagy a referenciaállamok eredményeit megismerik, az érintett kormányok számára ez már nem egyszerủen oktatáspolitikai probléma, hanem egyenesen külpolitikai. Soha ezelőtt nem történt meg, hogy az oktatási rendszer jövője összefonódjék a külpolitikával. Így válik az eredeti tanulói teljesítménymérésekből fejlesztéspolitikai kihívás.

Az összehasonlítások (benchmarking) az OECD fö nyomásgyakorló eszköze; egyéb eszköze (finanszirozási források, politikai hatalom) nincs is. Az OECD kezében az összehasonlítások kormányok közötti versengéseket szülnek anélkül, hogy bármilyen célokat tételesen megfogalmaznának. A PISA vizsgálatok szakértői sohasem mondják, milyennek kellene lennie egy-egy oktatási rendszernek. Csak az eredményeket közlik, és ezekből az egyes kormányok levonhatják a következtetéseket. Az egyik elgondolkod- 
tató PISA-eredmény az ázsiai országok PISA-n mért, visszatérően magas eredménye, különösen, ha egybevetjük az adott országok oktatási rendszerével és pedagógiájával.

Nem állítjuk, hogy az összefüggés szándékos lenne a PISA-nyertes rendszerek Sanghaj, Szingapúr, Hongkong, Tajvan, Dél-Korea, Makaó (Kozma 2015) - és az OECD filozófiája között. Azt azonban megkockáztatjuk, hogy a PISA-sikeres országok kormányzatai sikeres partnerek az OECD számára. A gazdaságfejlesztés, ahogyan a szervezet fölfogja, erős kormányzatot, befelé konszolidált politikai környezetet, kifelé pedig együttműködő (gazdaság-)politikát igényel (OECD 2021c; OECD 2021f; OECD 2021j). Éppen mint a sikeres PISA vizsgálatok.

\section{Új fordulat: Kelet-Közép-Európa}

Az OECD 1993-1996 között megérkezett Kelet-Közép-Európába. Az új tagállamok közül az első Magyarország volt (kérelmet adott be 1993-ban, fölvételt nyert 1996-ban, vö. OECD 2021d, OECD 2021e, OECD 2021f); az eddigi utolsó pedig Litvánia (2018). Ez nemcsak az egykor megszállt (Szovjetunió) országok számára volt új fejlemény, hanem az OECD számára is. Nemcsak a „piaca” tágult világméretűvé - bejutott az egykori vasfüggöny mögé -, hanem a problémák, amelyekkel szembesült is új tudásokat és kompetenciákat igényeltek (Jobb szakpolitikákkal a jobb életért, OECD 2021c). A ,jobb szakpolitikák" természetesen nagyobb szakértői hálózatot igényeltek, ami a szervezeti növekedést és az adminisztráció megnövekedését is magával hozta. Az OECD az 1990-es évek átalakulásai során a „fejlett országok” viszonylag szűk köréből - azok gazdasági tanácsadó cégéből - valódi világszervezetté vált, amely a legfejlettebb országoktól a fejlődésben lévőkig (Costa Rica, Chile, Izrael) átfogja a különböző szinten lévőket. Az 1990 óta fölvettek újabb igényeinek megfelelően a szervezet tevékenysége egyre szélesebb körben érinti a tagállamok szakpolitikáit. (Az oktatáskutató számára ebből a széles körű tevékenységből természetesen az oktatáspolitika a leginkább releváns, mint azt elözőleg már jeleztük. Ezt szokták oktatáskutató körökben az OECD-vel azonosítani.)

A dilemma azonban maradt ugyanaz. A megoldások annál törékenyebbek, mennél bonyolultabb a terep, amelyet a szakpolitika lefed. A fizikai infrastruktúra fejlesztését szabványos technológiával meg lehet oldani - a humán infrastruktúra fejlesztéséhez a technológiai transzfer nem elég. Ez a nemzetközi tanácsadás új kihívása. Annál is inkább, mivel egy-egy tagállam szakpolitikái összefüggenek egymással - és a rejtett összefüggéseket még a legfölkészültebb szakértő is nehezen (vagy sehogy sem) érti meg. Ez vezet az OECD vitatott kezdeményezéseihez - pl. migrációs politikában, menekült kérdésben (OECD 2021f) -, amelyek nyilvánosságot is kapnak annak ellenére, hogy a szervezet igyekszik kézben tartani az információkat.

$\mathrm{A} z$ új piacokkal nemcsak új célok jártak, hanem az OECD szervezetének átalakulása is. A látványosan kiszélesülő szakpolitikai tanácsadás - szükségletek fölmérése, fejlesztési célok együttes kijelölése, értékelés, visszacsatolás, médiakampányok - bürokratikus nagyszervezetté alakította az OECD-t. Megközelítése és megértése - az arra való törekvés - egyre bonyolultabb, idézve a korszerü bürokráciaelemzéseket (bürokráciaelemzések vö. Pierre 1995: 1-31; Bendor 1994). Kelet-Közép-Európa megnyitása mindkét félnek átalakulást hozott. A visegrádi országok, köztük Magyarország 
számára gazdasági-politikai elfogadottságot; az OECD számára pedig a funkciók megváltozását és a szervezet átalakulását.

Magyarországon az OECD kezdetben meglehetősen ismeretlen volt. A belépés problémái megmaradtak a kormányzati körökben. Számos nemzetközi szervezettel - mindenekelőtt a Világbankkal, a NATO-val és az Európai Gazdasági Közösséggel - való kapcsolatépítés sürgősebb és fontosabb volt (Mong 2012: 150-156). Ehhez képest az OECD fölkeresése, úgy látszott, ráér. Inkább egyes szakterületek szakértői sürgették (pl. az oktatás), miközben a kormányzati szervezetek még csak tájékozódtak. Az információhiány kölcsönösnek mutatkozott. Ezért is húzódott a kilencvenes évek közepéig Magyarország belépése az OECD-be.

A bizonytalanság éveit a szakértői viták uralták. Közülük az oktatáspolitikai vitákat ismerjük leginkább (vö. Lukács-Várhegyi 1989; Forray-Kozma 1991; Kozma 1992). E vitákat nem lehet közvetlenül az OECD-belépéshez kötni. A szakértők az 1990-es évtized első felében mindenképp hallatni akarták a hangjukat, formálni próbálva a kialakulatlan oktatáspolitikát (ezt a szerepet tanulták meg és gyakorolták az 198090-es évtized fordulója óta, vö. Kozma 2010). Az OECD-hez való közeledés a hazai vitákban egyelőre nem játszott szerepet. Az OECD ebben az időben meglehetősen távoli és érdektelen szervezetnek látszott ahhoz, hogy súllyal lehessen hivatkozni rá a hazai oktatáspolitikában.

A hazai szakértők egy szükebb köre figyelt csupán az OECD szakmapolitikai kezdeményezéseire. Azok, akik - főleg az UNESCO teljesítménymérései révén - a politikai viták helyett az oktatáspolitikát tudományos alapokra igyekeztek helyezni. Számukra az OECD vonzónak és ígéretesnek látszott, mert megtestesített egy funkcionalista-tervező magatartást a vele összefüggő tudásokkal és készségekkel, amely teljesen hiányzott a konfliktusos-kritikus szakértőkkel (Bajomi 2010). Ez a kör lett később az OECD igazi hazai szakértői gárdája, amelyre a megjelenő szervezet hazánkban is számíthatott.

$\mathrm{A} z$ OECD hazai fogadtatásának története azt mutatja, hogy az intézeteik zártságából kiszabaduló szakértők útja kettévált. Azokból, akik hajlamosak voltak az oktatáspolitikát kritikai-konfliktusos módon megítélni, lettek a későbbi „oktatáskutatók”. Azokból pedig, akik funkcionalista-tervező magatartással igyekeztek befolyásolni az oktatáspolitikát, kormányzati szakértők lettek.

Utóbbiakat legitimálta az, hogy Magyarország belépett az OECD-be. Mint kormányzati szakértők, visszatérően ki voltak téve a hazai kormányzat mindenkori változásainak - az 1990-es években az oktatási kormányzat vezetői kétévente változtak -, de a nemzetközi szervezetekkel, köztük az OECD-vel tartott kapcsolataik valamennyire mégis folyamatossá tudta tenni a tevékenységüket.

Így vált Magyarországon az OECD egy szük csoport hivatkozássá - távol iskolától és „katedrapedagógiától”. Az OECD-re hivatkozók helye mind a kormányzati hivatalnokok, mind a tudományos kutatók között marginális. Egy-egy PISA vizsgálatnak a médiában folyó csinnadrattája közben mégis ők azok, akiket a kétségbeeső politikusok megkeresnek. 


\section{Összefoglalás}

Ebben az írásban az OECD-t mint „túlélő szervezetet” mutattuk be. Egy több mint háromezer fős szervezetet (titkárság: 3300 fó, 2018-ban) az adott terjedelemben lehetetlen analizálni; legföljebb a sziluettjét rajzolhatjuk meg. Helyenként élesebb, helyenként elnagyoltabb vonásokkal, hogy a madártávlatú kép jellegzetességei jobban kiemelkedhessenek.

"Túlélő szervezeten” olyan szervezetet értünk, amely elvesztve eredeti funkcióját, új társadalmi szükségletet keres, hogy azt betöltve tovább tudjon müködni és életben maradhasson. Ilyen túlélő szervezetnek láttatjuk az OECD-t, amely betöltve eredeti funkcióját a megsemmisülés szélére sodródott - mégis képes volt túlélni (1961). Számos szervezeti válságon túljutva az 1970/1980-as évekre az OECD a legfejlettebb országok "gazdasági tanácsadó" irodájává vált, és ennek megfelelően alakult a szervezete is.

Az OECD 1996-ben érkezett meg Kelet-Európába azzal, hogy Magyarország belépett a szervezetbe. Ez mindkét fél részére számottevő változást hozott. Az OECD gazdasági tanácsadó cégből szakpolitikai kutató, értékelő és fejlesztő irodává, bürokratikus nagyszervezetté vált. Tagsága (36 ország, 2018) ma már nemcsak a legfejlettebbek, hanem azok a fejlődők is, akik úgy határoznak, hogy az OECD szakpolitikai tanácsaira szükségük van, nem utolsósorban nemzetközi kapcsolatrendszerük erősítéséhez. Közéjük tartozik Magyarország is, külkapcsolatainak egyfajta hátterezése és hitelesítése végett.

Amikor az OECD megjelent Magyarországon (a rendszerváltozás első szakasza) a rendszerváltozás oktatáspolitikai vitái javában dúltak. E viták közben a szakértők két csoportja formálódott ki. Az egyikből (kritikai-konfliktusos) lettek az „oktatáskutatók”, a másikból (funkcionalista-tervezö) pedig a „szakértők”. A mindennapi életben csak kevéssé látszanak. De amikor a kormányzati oktatáspolitikát egy-egy valós kihívás éri, kiderül, mennyire fontosak.

\section{IRODALOM}

Вајом I. (2010) A közpolitika-barkácsolás szereplői és színterei. Educatio, Vol. 19. No. 4. pp. 584-600.

Bendor, J. (1994) The Fields of Bureaucracy and Public Administration. Journal of Public Administration, Research and Theory, Vol. 4. No. 1. pp. 7-39.

Forray R. K. \& Kozma T. (1991) Hány plusz hány? Budapest, Oktatáskutató Intézet.

Feitsma, J. \& Schillemans, T. (2018) Behaviour Experts in Government. In: S. Beck \& H. Strassheim (eds) Handbook of Behavioural Change and Public Policy. Cheltenham (UK), Edward Elgar Publishing (ElgarOnline). https://ssrn.com/abstract=3250352

Ferguson, N. (2019) A tér és a torony. Budapest, Scolar Kiadó.

Ferguson, N. (2020) A világ háborúja. Budapest, Scolar Kiadó.

HaAs, E. B. (2008) Beyond the Nation-State. Colchester (University of Essex, UK), ECPR European Consortium of Political Research.

Halász G. \& Fazekas Á. (2021) A tudás keletkezése. Budapest, Gondolat Kiadó.

Kearns, P. \& Papadopoulos, G. (2000) Building a Learning and Training Culture. Melbourne, Australian National Training Authority. 
KIss Á. - Nagy S. \& Szarka J. (1979, eds) Tanulmányok a neveléstudomány köréböl 1975-1976. Budapest, Akadémiai Kiadó.

Kozma T. (1992) Reformvitáink. Budapest, Educatio Kiadó.

Kozma T. $(1999,2001)$ Bevezetés a nevelésszociológiába. Budapest, Nemzeti Tankönyvkiadó.

Kozma T. (2010) Rejtőzködők és leleplezők. Educatio, Vol. 19. No. 4. pp. 525-534.

Kozma T. (2015) Például Szingapúr. Education, Vol. 23. No. 2. pp. 2-8.

Lukács P. \& VÁrhegyi Gy. (1989, eds) Csak reformot ne... Budapest, Educatio Kiadó.

Márkus, E. \& Kozma, T. (1989, eds) Learning Communities and Social Innovations. Debrecen, University Press.

Mayntz, R. (1969) Soziologie der Organisation. Hamburg, Rowohlt Verlag.

Mezei G. (2001) Helyreállitott Európa. Budapest, Osiris Kiadó.

Mong A. (2012) Kádár bitele. Budapest, Libri Kiadó.

Morawski, W. (1979, ed.) A szervezet. Budapest, Közgazdasági és Jogi Kiadó.

Moulaert, F., MacCallum, D., Mehmood, A. \& Hamdouch, A. (2013, eds) International Handbook of Social Innovations. Cheltenham (UK). Edward Elgar Publishing.

OECD (2020) Education at a Glance 2020. Paris, OECD. https://www.oecd-ilibrary.org/ sites/69096873-en/index.html?itemId=/content/publication/69096873-en [Letöltve: 2021. 05. 03.]

OECD (2021a) Centre for Educational Research and Innovation. Paris, OECD. https://www. oecd.org/education/ceri/brochure.pdf [Letöltve: 2021. 05. 03.]

Papadopoulos, G. (1994) Education 1960-90: The OECD Perspective. Paris, OECD.

Pierre, J. (1995) Bureaucracy in the Modern State. Cheltenham (UK), Edward Elgar Publishing.

PISA (2015) Kritika és védelem. In: Kozma T. \& Pusztai G. (eds) Educatio, Vol. 24. No. 2. pp. 3-111. Tematikus szám.

Polónyi I. (2002) Az oktatás gazdaságtana. Budapest, Osiris Kiadó.

Rizvi, F. \& Lingard, B. (2009) The OECD and Global Shift in Education Policy. In: R. Cown \& A. M. Kazamias (eds) International Handbook of Comparative Education. Berlin, Springer Verlag. pp. 437-453.

Strassheim, H. \& Beck, S. (2019, eds) Handbook of Behavioural Change and Public Policy. Cheltenham (UK), Edward Elgar Publishing (ElgarOnline).

Szczepański, J. (1969) A felsőoktatás szociológiája. Budapest, Felsőoktatási Kutató Központ.

Szentpéteri, I. (1985) A szervezet és a társadalom. Budapest, Közgazdasági és Jogi Kiadó.

Tudásszintmérés világszerte (1971) Szerkesztette és fordította: BáthORY Zoltán. Budapest, Tankönyvkiadó.

\section{INTERNETES FORRÁSOK}

Valamennyi letöltve: 2021.05. 03.

OECD (2021b) School Resources Review. https://www.oecd.org/education/schoolresources-review/

OECD (2021c) Az OECD honlapja: https://www.oecd.org/

OECD (2021d) Az OECD Magyarország-elemzései: https://www.oecd-ilibrary.org/ economics/oecd-economic-surveys-hungary_19990529 
OECD (2021e) Az OECD Magyarország országtanulmányai: https://www.oecdilibrary.org/economics/oecd-economic-surveys-hungary_19990529

OECD (2021f) Az OECD Nemzeti Tanács honlapja: https://oecd.kormany.hu/

OECD (2021g) What is the OECD? https://www.youtube.com/user/oecden

OECD (2021h) Principles, https://www.youtube.com/watch?v=T8rMS2nKMmI

OECD (2021i) Competency Framework. https://www.oecd.org/careers/competency_ framework_en.pdf

OECD (2021j) The OECD 60th Anniversary: Forging a Path for Better Lives. https:// www.youtube.com/user/oecden

A cikk a Creative Commons Attribution 4.0 International License (https://creativecommons.org/licenses/ by/4.0/) feltételei szerint publikált Open Access közlemény, melynek szellemében a cikk bármilyen médiumban szabadon felhasználható, megosztható és újraközölhető, feltéve, hogy az eredeti szerző és a közlés helye, illetve a CC License linkje és az esetlegesen végrehajtott módosítások feltüntetésre kerülnek. (SID_1) 